\title{
Rural Poverty and Social Work: Three Models
}

\author{
Rajendra Baikady ${ }^{1}$, Venkat Pulla ${ }^{2, *}$, Channaveer R.M. ${ }^{1}$ \\ ${ }^{1}$ Department of Social Work, Central University of Karnataka, Gulbarga, India \\ ${ }^{2}$ Social Work Discipline, Australia Catholic University, Brisbane, Australia
}

\begin{abstract}
This paper discusses some innovative social work response to poverty in India at the community level promoted by volunteers and professional social workers alike. Three case studies in relation to poverty in India are reviewed and suggest that there is a great need for inclusion of specific content in social work training around poverty and working with poverty groups. Suggestions such as legal and regulatory framework for social work training and practice are also forwarded.
\end{abstract}

Keywords Poverty, Global Poverty, Social Work, Social Work Education, Innovation

\section{Introduction}

Poverty is a multi-dimensional social problem. The problem of poverty is a vicious circle as the low level of investment is the outcome of low levels of savings and the circle of poverty goes on indefinitely as the yield of low savings and investment contributes. According to the World Bank (2015), poverty levels across the globe have declined; in 1990 nearly half of the population in the developing regions lived on less than $\$ 1.25$ a day. This rate dropped to 14 per cent in 2015 . In other words, global poverty rates fell from $36 \%$ in 1990 to $14 \%$ in 2011(World Bank 2015). The aim of the article is to find the innovative ways for poverty reduction and to enhance the human wellbeing. Government policy on poverty eradication is to increase the number of facilities available and to improve the quality of services for the community. (Mona Serageldin, et al 2006).

Poverty is a condition in which the people face general scarcity or dearth of the basic human necessities, poverty is also a state of one who lacks a certain amount of material possessions or money which is needed for the normal life of an individual. The related term Absolute poverty or destitution refers to the deprivation of basic human needs, which commonly includes food, water, sanitation, clothing, shelter, health care and education and the relative poverty is economic inequality in the location or society in which people live (UN 2006). The poverty is a phenomenon in
India and some of the other developing countries which are still struggling to overcome poverty. Including the Indian government the efforts had been made by the United Nations to elevate the global poverty and to make the world free of hunger. When India earned its independence from the Britishers the economic condition of the country was very poor and the living condition of the people was unbearable. The government in India is failing to respond to the basic needs of the people because of the constraints on government's ability to deliver services, such as corruption, tax avoidance, debt and loan conditionality's and by the brain drain of health care and educational professionals. Hence the government has to take steps to prevent social problems and to find the strategies of increasing income to make basic needs more affordable typically include welfare, economic freedoms, and providing financial services. Poverty reduction is a major goal and issue for many international organizations. The United Nations and the World Bank are also actively involved in building the strategies for the poverty reduction in the world. According to the World Bank (2015), it is estimated that 1.29 billion people were living in absolute poverty in 2008, out of which, about 400 million people in absolute poverty were found in India. Between 1990 and 2010, about 663 million people moved above the absolute poverty level.

\section{Defining Poverty}

Defining poverty is the most difficult task because the poverty is a multi-dimensional phenomenon which relates with social-economic cultural and the political conditions of the people and the society. An attempt is made to quote the most suitable definition of the poverty in this article. The definition given by United Nations (1998) refers poverty as the inability of getting choices and opportunities, a violation of human dignity. The meaning of the definition says that the poverty is lack of basic capacity to participate effectively in society and it also means not having enough to feed and clothe a family, not having a school or clinic to go to; not having the land on which to grow one's food or a job to earn one's living, not having access to credit. It means insecurity, 
powerlessness and exclusion of individuals, households and communities. It means susceptibility to violence, and it often implies living in marginal or fragile environments, without access to clean water or sanitation.

\section{Factors and Causes of Poverty}

Poverty is not restricted to one or the two countries of the world or not even one or the other part of the world, poverty is a global phenomenon which is creating an obstacle for the overall development of the world in general and a country or a region in particular. A report by the World Bank (2015) indicates that globally, extreme poverty has declined significantly. In 2011, one billion people-14.5 percent of the world's population - could be classified as extremely poor, down from 1.25 billion - or 18.6 percent of the world's population - in 2008. But still almost half the population in the developing countries lives on a dollar or less a day which is absolutely below the statistical measurement of the poverty line World Bank (2015). Among the Asian countries 450 million of the poor live in India, 225 million in People's Republic of China, and 55 million in Southeast Asia (UNDP, 2006, 2007).

Poverty elevation is the foremost concern of the every society as the vicious circle of poverty effects the all-round development of the country at large and the community at micro level. There are many innovative and the replicable models for the poverty reduction in India and we will restrict to describing three such models.

\section{Mazdoor Kisan Shakti Sangathan, (MKSS)}

As a social movement MKSS was set up in 1990s for the protection of the rights of the farmers, workers and the peasants and to strengthen the democratic participatory process of the people in the administration. The core aim this movement is to bring the dignity and social justice to the ordinary citizens of the state. The organization contributed greatly for the enforcement of Right to Information Act (RTI) through which demands for minimum wages for workers was ensured. MKSS is a classic example for a non- political people's organization which is working in the state of Rajasthan. One of the most important innovations of the MKSS been the method of Jan Sunwais or Public Hearings where detailed documents derived from official expenditure records were read aloud to the people of the villages who gathered. Jan Sunwais are organised independent of the government but government officials are invited to attend. In the form of a hearing, people are invited to give their testimonies which often reveal differences between official records and people's experiences. Some of the major areas where MKSS worked are, right to information, where the people of the villages where trained to demand for the financial records of the government expenditure. This was a stepping stone initiative in the accountability. Through the process called our money; our account the villagers started collecting the documents of the government expenditure and the records then closely examined by the people concerned panchayat. After this process the public hearing were organized in order to accommodate the residents of the village to verify and audit the work of their panchayat, through this process the MKSS tried to bring out the knowledge of transparency, accountability, redressal in the public work. The first Public Hearing the MKSS organised in December 1994 established the importance of information for the people, and exposed the official opposition to disclosure of records. This flagged off the struggle for the people's Right to Information. In the present society the right to information is playing a very major role in the public life of the citizens of the country, the initiative started from a small village of Rajasthan. Another initiative of the movement was the right to know; the right to Live which lead to the national campaigning for demanding the right to information. As a part of this campaigning the national campaigning for the people's right to information was established in 1996. As an effort of this campaigning Since 1996, Right to Information Laws have been enacted in the States of Tamil Nadu (1996), Goa (1997), Madhya Pradesh (1998), Rajasthan (2000), Maharashtra (2000), Karnataka (2000), Delhi (2001), Assam (2002), and Jammu and Kashmir (2003). Work for all as well as Just wages for all is the one more initiative by MKSS for ensuring the minimum wage for the workers.

\section{RUDSET Experiment}

Unemployment is the one major cause for the poverty of Indian citizens, unlike other developing countries unemployment is the prime challenge India is facing in the process of its development. Given the development in the educational and skill development lakh of youth with relatively employable skills are entering the job market every year after completing their school/collegiate education. The country and the economic development of the country is still not able to provide the value based well suitable employment to each and every citizen accordance to his skill and qualification. The rural part of the India depends entirely on the Agricultural economy and unfortunately agricultural economy also appears to have reached a saturation level leading to large scale migration of manpower from rural areas to urban areas adding woes and pressure to already over strained civic infrastructure. The need for increasing the self-employment opportunity for these educated and oriented towards the white collar job youths. One of such innovative experiment is that Rural Development \& Self Employment Training Institute (RUDSETI) a unique initiative in mitigating the problem of unemployment was taken a way back in 1982. RUDSETI has shown remarkable progress in 
(i) Promoting rural entrepreneurship, (ii) Employment generation in rural areas, (iii) Resource utilization \& capital buildup (iv) Demystification of technology, (v) Creating awareness, (vi) Confidence building in rural youth (vii) Empowerment of women (viii) Promotion of service sector (ix) Building up of human capital. The success of the Micro Enterprises shows that the youths who have started Micro Enterprises are earning in the range of Rs. 2500/- to $30000 /-$ per month. In good number of cases, the earning has crossed Rs. 50,000 per month which is a major contribution for the poverty eradication as it contributed to the national wealth to the tune of Rs. 300 Crores per annum at an average earning of Rs 2500/- per month per successful trainees.

The institute provides different kinds of self-employment training to the youth which makes the youth self-reliant and productive. The contribution of the institute to the life of the youth in the nation is remarkable as - Ms. Renuka Kumar, Deputy Secretary, MORD, GOI, and New Delhi, says "It is a pleasure to see such a smooth, well run establishment. My personal compliments to staff and promoters of RUDSETI for having conceived such a good intervention and converting the idea into reality. The institute has all the ingredients for being adjudged a centre of excellence".

\section{Ralegan Siddhi Ideal Village}

Ralegan Siddhi is a village in Parner taluka of Ahmednagar District, Maharashtra state in western India. The village was affected by drought during 1975 and the acute poverty was one of the major problems of the country at that point of time. Illicit liquor trade was also effected the life of the people during the same time. Because of the dame wall leak the village tank could not hold water for the people and the animals. During this critical situation the Indian well known social activist Anna Hazare encouraged the village people and introduced the changes in the village. He motivated the people to embark the water tank by mutual help as a result the wells of the village were filled and now this village is considered a model of environmental conservation. Now the village has water year round, as well as a grain bank, a milk bank, and a school. There is no longer any poverty. This village is truly environmental friendly as it uses the solar energy for most of its work. The World Bank Group has concluded that the village of Ralegan Siddhi was transformed from a highly degraded village ecosystem in a semi-arid region of extreme poverty to one of the richest in the country. The Ralegan Siddhi village development example is, now 25 years old, by demonstrating that it is possible to rebuild natural capital in partnership with the local economy, is a model for the rest of the country.

\section{Role of Social Work}

Eradicating poverty is the one major area of concern of the government in every country. The policies and the programmes for the poverty reduction aim to improve the wellbeing of the people. Social work that adheres to principles of human rights and social justice and is concerned about the empowerment is required to play a major role in a country like India through governmental agencies and the Civil Society. At the policy level, there is a need to establish a legal framework for social work training and practice in order to increase professionalism and professional identity (Twikirize, et .al 2013). A critical area is the need to initiate avenues and mechanisms for continuous professional training that is related to poverty alleviation programmes. The social work practice at the local level should take in to account the key areas of intervention including culturally relevant/sensitive practice, multidisciplinary approaches to intervention and increasing social work role in research, policy influence/development and advocacy, among others is the another way to indigenize the social work practice and use it for the poverty reduction programmes.

Social work as a service profession helps the individuals, groups, and the communities to identify the problems and helps the people to solve those problems. The poverty reduction programmes and the policies formulated and monitored by the government can be successfully managed by the social work. The social work can promote the individual development by Encouraging and supporting individuals and households to start income-generating activities (IGAs): this activity will support the community people to come out of the lack of employment or under-employment, and the resultant lack of incomes or low incomes. This income generating strategy can support entire communities including the vulnerable groups like women, youths, the elderly, refugees, and orphans and other vulnerable children (OVC).

Social worker in the communities is considered as the mobilizer. The resource mobilization is the major task for the social worker to promote the development of the community and the lives of the people in the community. The social work as a profession may involve ether remedial approach or the developmental approach for the resource mobilization and development. The remedial approach involves giving relief assistance in form of food, accommodation and medical care to some social groups such as refugees. The developmental approach is, some agencies providing grants, improved seeds. Hence the social work can be a very active partner in the development of the people with any one of the approach. Ultimate aim of the both approaches is to develop the community and elevate poverty. The financial development of the people is the one alternative for poverty reduction, the financial development helps reduce poverty indirectly by stimulating growth and directly by facilitating translations and allowing poor to benefit from financial services that increase their income and enhance their ability to undertake profitable investee met and other activities (Jeanneney and Kangni Kpodar (2010).The capacity building in the community means addressing the underlying problem of limited practical knowledge and skills in 
production processes, as well as powerlessness. Hence the capacity building will help the community to develop the resistance. Capacity building largely involves training and providing information to entire communities and vulnerable social groups such as farmers, women, orphans and vulnerable children, youths, the elderly and community leaders.

Social work profession may be a great support for the poverty reduction at the local level, if the programmes and polices related to the social work and the social work education are thoughtfully created. Currently there is no statutory status for social work as a profession in India responsible for meeting the social welfare needs of the people. The lack of organization among the social workers around the globe as well as at the local level results in lack of strong identity. Limited employment opportunities available for the social workers with in the frame work of social work and social development is also one of the major problems which is leading to the waste of the resources spent on training social workers. There is a huge demand for the trained social workers but the job of a social worker in India is not a well-paid and many of the social workers end up taking on the first job opportunity that presents itself even when it does not require such specialist training. Lack of appreciation of the role of social work is leading to the de valuing of the profession. The role of social work is less understood among the people in the community. Unless in some countries the social work is not having a government mandate or government support for the practice and not even the social work is legally accepted profession.

In India for instance, access to clean water and sanitation is one of the most cost-effective development interventions and critical for reducing poverty. The clean water for the drinking and sanitation will reduce the health problem burden. There are people in the some parts of the world leaving without safe drinking water and sanitation facilities. To date there are around some 2.5 billion people without safe sanitation and 783 million without safe drinking water. Diseases caused by unsafe drinking water and poor sanitation are the most significant child health problems worldwide. Hence the water and sanitation and education for the attitudinal change of the people towards the sanitation in the society are a gray area for the social work in the near future. There is a great need for the social work profession to develop the professionalism and professional identity. For this purpose there is a need to strengthen the legal and regulatory framework for social work training and practice with in India. It is critical for the government to move and delineate practice areas where mandatory social work qualification is required given the profession's core skills and competences and its key role in promoting social development. The existing critique that most social work practices in the context of India's social work is imported and hence the plea for innovative indigenization of social work is very relevant. The curricular changes are required in schools of social work that will orient students towards the poverty reduction and the social problem prevention based strategies. Poverty reduction strategies should be underlined in the curriculum so that practitioners are equipped with adequate knowledge and skills in addressing poverty and contributing to its reduction. The strategies that cover the three priority sectors of agriculture, education and health need to be accentuated in training. For the betterment of the poorest in the society the local authorities need to play a much greater role in provision and eradication of poverty and intervention services. Access to quality of life contributes to the social, emotional and educational development of the population.

\section{Acknowledgments}

The authors are grateful to two sets of blind referees that have commented on our earlier drafts.

\section{REFERENCES}

Twikirize, N Asingwire, J. Jomona, R. Lubanga, A. Kafuko (2013), the role of social work in poverty reduction and realization of millennium development goals in Uganda. Fountain Publishers, Kampala.

Poverty Reduction: How and Where We Work. (2013, February 19). Retrieved August 18, 2016, from

http://www.worldbank.org/en/news/feature/2013/02/05/povertyred uctioninpractice

Philanthropies, T. A. (2012, September). Social work alleviates poverty. Retrieved August 19, 2016, from

http://www.atlanticphilanthropies.org/news/social-work-alleviatespoverty

Sylviane Guilloumount Jeanneney\& Kangin Kpodar (2011), Financial development and poverty reduction; can there be a benefit without a cost?, the journal of development studies 47; 1, 143-163

Serageldin, M., Solloso, E., \& Valenzuela, L. (2005, May ). Local government actions to reduce poverty. Retrieved August 19, 2016, from

http://www.globalurban.org/GUDMag06Vol2Iss1/Serageldin, \%20 Solloso,\%20\&\%20Valenzuela.htm

Fact sheet 2014 global statistics, MDG 6: 15 years, 15 lessons of hope from the aids response,

http://www.unaids.org/sites/default/files/media_asset/20150714_F S MDG6 Report en.pdf retrieved on 10/09/2015.

Nations, U., Economic, D. of, \& Affairs, S. (2006). Social justice in an open world, the role of the United Nations: The international forum for social development. United States: United Nations.

Markey, H. (2013, November 21). Poverty statistics. Retrieved from Prezi, https://prezi.com/xbnwgi4hg1fl/poverty-statistics/

mkss. MKSS about us. Retrieved August 20, 2016, from http://www.mkssindia.org/mkss-about-us/

United Nations (2011). Population Distribution, Urbanization, Internal Migration and Development: An International Perspective. In Department of Economic and Social Affairs Population Division 